\title{
MICROBIAL DETERIORATION OF VACUUM-PACKAGED CHILLED BEEF CUTS AND TECHNIQUES FOR MICROBIOTA DETECTION AND CHARACTERIZATION: A REVIEW
}

\author{
Maria Lucila Hernández- Macedo ${ }^{*}$, Giovana Verginia Barancelli ${ }^{2}$, Carmen Josefina Contreras- Castillo ${ }^{1}$ \\ ${ }^{1}$ Escola Superior de Agricultura Luiz de Queiroz, Departamento de Agroindústria, Alimentos e Nutrição, Universidade de São \\ Paulo, Piracicaba, SP, Brasil; ${ }^{2}$ Faculdade de Zootecnia e Engenharia de Alimentos, Universidade de São Paulo, Pirassununga, SP, \\ Brasil.
}

Submitted: September 08, 2009; Returned to authors for corrections: April 04, 2010; Approved: July 04, 2010.

\begin{abstract}
Gas production from microbial deterioration in vacuum-packs of chilled meat leads to pack distension, which is commonly referred as blown pack. This phenomenon is attributed to some psychrophilic and psychrotrophic Clostridium species, as well as Enterobacteria. The ability of these microorganisms to grow at refrigeration temperatures makes the control by the meat industry a challenge. This type of deterioration has been reported in many countries including some plants in the Midwestern and Southeastern regions of Brazil. In addition to causing economic losses, spoilage negatively impacts the commercial product brand, thereby impairing the meat industry. In the case of strict anaerobes species they are difficult to grow and isolate using culture methods in conventional microbiology laboratories. Furthermore, conventional culture methods are sometimes not capable of distinguishing species or genera. DNA-based molecular methods are alternative strategies for detecting viable and non-cultivable microorganisms and strict anaerobic microorganisms that are difficult to cultivate. Here, we review the microorganisms and mechanisms involved in the deterioration of vacuum-packaged chilled meat and address the use of molecular methods for detecting specific strict anaerobic microorganisms and microbial communities in meat samples.
\end{abstract}

Key words: Vacuum-Packaged Meat, Spoilage Microbiota, Blown Pack, Molecular Biology.

\section{INTRODUCTION}

One of the challenges currently facing the meat industry, which carries out the slaughter and marketing of bovine meat, is the "blowing" of packages of vacuum-packaged chilled meat by microorganisms. The first scientific report of pack distension in vacuum pack chilled meat was in 1989 (16). This type of deterioration has also been described in several countries and attributed to Clostridium estertheticum, $C$. gasigenes, C. algidicarnis and C. putrfaciens $(7,8,9,16)$. In Brazil, work has been published recently on vacuum-packaged chilled meat microbes from meat-packing plants in the Midwestern and Southeastern regions by Rauecker et al. (52, 53), after by Felipe et al., 2008 (24), Rosa et al. 2009 (57) and Hernández-Macedo et al., 2009 (35).

In general, deterioration is a subjective judgment that can

*Corresponding Author. Mailing address: Escola Superior de Agricultura Luiz de Queiroz - Departamento de Agroindústria, Alimentos e NutriçãoUniversidade de São Paulo.; E-mail: lucyherma@ hotmail.com 
be influenced by economic and cultural aspects, knowledge, the sensory acuity of the individual and intensity of deterioration. In the case of meat, the main criteria for rejection are a change in color, undesirable odor and slime formation (51). Depending on the type and intensity, the deterioration of meat can cause immediate rejection by consumers. The production of gas by microorganisms in vacuum-packaged chilled meat causes pack distension, a phenomenon known as blown pack, which prevents the acceptance of the product. Despite the importance of Brazil in the production and export of meat, there is a relative scarcity of research on the microbial deterioration of vacuum-packaged meat in the country.

For fresh meat, vacuum packaging has proven to be efficient in extending shelf life, preserving the sensory characteristics inherent to the product for a period sufficiently long for its turnover. During refrigeration, the vacuum allows the shelf life of the meat to be extended by reducing oxidation and the growth of aerobic microorganisms. Of the established meat packaging systems, the vacuum has been the most widely used in the institutional market for the distribution of whole pieces (59). In North America, approximately 85\% of fresh meat and most processed meats are packed in a modified atmosphere, including the vacuum system (36).

The deterioration of thermally processed or vacuumpackaged chilled raw products - like meat - is frequent; sometimes it occurs in large proportions of the same batch. The bacteria that have been isolated from vacuum-packaged products have been characterized as either new species or as species that were previously considered to be harmless. Examples of such species include Clostridium species, which are able to grow under refrigeration, Carnobacterium spp., Leuconostoc carnosum, Leuconostoc gelidum, Lactobacillus sake, Lactobacillus curvatus, and atypical or not identifiable lactobacilli, Brochothrix thermosphacta, Enterococcus spp., Serratia liquifaciens, Hafnia spp., Proteus spp. and some others from the Enterobacteriaceae family. These bacteria are present in the environment but are probably not the dominant species of the microbiota. For meat contaminants, the use of modified atmosphere / vacuum and long-term storage at refrigeration temperatures may promote the growth of some of these bacteria, allowing them to become dominant and deteriorate the product (55).

For strict anaerobic microorganisms, such as certain Clostridium species, cultivation in conventional food microbiology laboratories is difficult because it requires highly reduced mediums and the use of special equipment and systems with strict anaerobiosis. Here, we will review aspects of the deterioration of vacuum-packaged chilled meat and the microorganisms that are involved in this process. We will also address the use of molecular methods as an alternative to conventional microbiological methods for the detection of specific strict anaerobic microorganisms and studies of microbial communities in meat samples.

\section{General aspects of meat deterioration}

The initial contamination of meat occurs during bleeding, due to the use of non-sterile equipment, and introduces microorganisms into the vascular system. Microorganisms that are introduced in this way may spread in the body of the animal due to the short persistence of the blood flow after bleeding (34). Subsequent contamination may occur in various stages, including slaughtering, cutting, processing, storage and distribution of meat. Sources may include water, facilities, equipment and manipulators. The skinning stage is particularly important, due to the high microbial load on the leather surface.

Fecal material, which may contain deteriorative microorganisms and pathogens, can also serve to as a source of microorganisms. The economic and public health consequences of the presence of microorganisms in food depend on the species and quantity present. The number of microorganisms present in the product determines whether the contamination will cause microbial deterioration or disease (25).

Meat is a semi-solid medium that is relatively low in sugar, which would feed bacteria (43). In the post rigor period, it is rich in non-protein nitrogen compounds, amino acids, creatine, peptides and proteins; the carbohydrate concentration is low, the $\mathrm{pH}$ is close to 5.5 , and the water activity $>0.97$ (55). 
The post mortem is associated with the conversion of muscle into meat. Subsequent storage and handling are concomitant with some deterioration of the meat, regardless of precautions taken. These changes are caused by microorganisms and exogenous enzymes, endogenous enzymes of the muscle, non-enzymatic chemical reactions, such as oxidative rancidity, and also physical effects, such as burning by cold, loss of fluid by dripping and discoloration. Although each of the above changes reduce the acceptability of the meat, microbial activity contamination is of utmost concern (34) and is the factor that most influences meat deterioration (51).

Fresh meat can be kept chilled or frozen; the maintenance temperature for the entire chain must be constant to ensure that the product keeps a uniform temperature. Meat is considered chilled when it is kept between -1.5 to $+7^{\circ} \mathrm{C}$ for the entire time following the post mortem process (48). The optimum storage and transport temperature for chilled meat is the lowest possible temperature at which no freezing occurs. Non-vacuum packed meat begins to freeze at about $-1.5^{\circ} \mathrm{C}$, and vacuumpacked meat starts to freeze at about $-2^{\circ} \mathrm{C}$ (depending on the type of meat and $\mathrm{pH}$ ). Thus, the aim is to reduce the meat temperature to $-1^{\circ} \mathrm{C}$ to $0^{\circ} \mathrm{C}$ as soon as possible after packaging (13).

Some species of bacteria are specific to meat, in that they can only be isolated from this substrate, slaughterhouses and related facilities. It is likely that meat combines the biochemical parameters that favor the growth of these bacteria. An example is B. thermosphacta, for which meat is considered an ecological niche (43).

The microbial spoilage of meat can be classified as aerobic or anaerobic, depending on the conditions under which it occurs and the microorganisms involved (34). The availability of oxygen determines the type of organism that will grow.

\section{The influence of vacuum packaging on the microbiota}

Vacuum packaging, which is used in the conditioning of whole pieces or small parts, aims to protect the meat product from contact with oxygen from the air. Oxygen promotes the growth of aerobic microorganisms, which can change the odor, color and appearance of meat products, cause oxidative rancidity of the fats, change the meat pigments and destroy vitamins and flavors (60).

Under aerobic conditions, Pseudomonas spp. can dominate the meat quickly and contribute to its deterioration $(29,47)$. Particular species that have been identified include $P$. fragi, the species most frequently isolated from meat, according to Labadie, 1999 (43), as well as P. fluorescens and P. putrefaciens (20). According to Lebert et al. 1998 (47), P. fragi becomes dominant in the meat during its refrigerated storage, perhaps due to the specifics of its metabolism and its shorter lag phase time. During refrigeration other important deteriorative microorganisms, such as those from the genera Moraxella, Psychrobacter and Acinetobacter, can also be found (20).

Vacuum-packaged meats are generally quite stable at low temperatures (43). While the shelf life of meat that is packaged with films that are highly permeable to oxygen is approximately one week, the shelf life of vacuum-packaged meat is around 3 to 12 weeks, when stored at $0{ }^{\circ} \mathrm{C}(29,17)$. Low temperatures prolong the storage time of meat; however, the lowest temperature that can be used without the product freezing $\left(-1.5^{\circ} \mathrm{C}\right)$ is higher than the minimum temperature for the growth of some psychrotrophic bacteria. Preventing growth of these organisms requires freezing (36). Despite the increased shelf life, fresh meat packed under vacuum will deteriorate after some time.

The permeability of the film affects the shelf life of the product. The vacuum packaging system uses flexible safe barrier films that have a low permeability to water vapor, aromas and gases, especially oxygen. The conservation of the vacuum inside the package is achieved by the complete removal of air from the headspace and appropriate sealing using heat-sealing machines. If the product contains dissolved oxygen, however, aerobic and microaerophilic microorganisms may still be able to grow at refrigeration temperatures. This can also occur if the material is relatively permeable to atmospheric oxygen. Thus, low concentrations of residual oxygen, 
especially in packages containing meat with a high $\mathrm{pH}$, will contribute to rapid deterioration (36).

In vacuum-packaged meat, the microbiota is determined by the environmental conditions: temperature, relative humidity, partial oxygen and carbon dioxide pressure will affect the growth potential of strict and facultative anaerobic microorganisms. In general, the level of vacuum that is used by the food industry is low. This level determines the amount of residual oxygen in the product and thereby the microbial development. During storage, however, the atmosphere changes. After evacuation, the remaining oxygen is consumed by both the metabolic activities of the meat and the bacteria present on the surface, which results in a lowering of the oxygen concentration to $1 \%$ and an increase in the carbon dioxide concentration to $20-25 \%$ (23). The $\mathrm{CO}_{2}$ released by the respiration of microorganisms inhibits the growth of aerobes. Thus, vacuum packaging is an anaerobic / microaerobic microsystem that delays the growth of aerobic bacteria such as Pseudomonas and promotes lactic acid bacteria, which have a lower potential for deterioration and limited growth at low temperatures (59).

Even under ideal conditions (lack of oxygen and chilled temperatures), food that is not cooked may harbor pathogenic, anaerobic and facultative anaerobic bacteria, which can grow during the storage of the product. These foods are expected to have a long shelf life, some up to 100 days. Thus, even an initial population of anaerobic or facultative anaerobic psychrophilic / psychrotrophic bacteria of $10^{1} / \mathrm{g}$ or less can multiply and achieve numbers that could cause deterioration or make the food insecure. If the food is submitted to temperature abuses, the situation is aggravated. Rapid growth of psychrotrophic as well as some mesophilic and facultative anaerobic bacteria that are unable to grow at temperatures lower than $5{ }^{\circ} \mathrm{C}$ can occur during short rises in temperature, drastically reducing the shelf life or safety of the product (56).

\section{Deterioration of vacuum-packaged chilled beef cuts}

In vacuum-packaged meat, psychrotrophic facultative anaerobic and anaerobic bacteria can grow and cause different types of spoilage (56). Typically, mesophilic bacteria are those that dominate the initial microbiota of vacuum-packaged meat (4). Storage conditions usually favor the growth of lactic acid bacteria in this type of product. However, there may be, occasionally, significant growth of the following psychrotrophic bacteria: Enterobacteriaceae, B. thermosphacta, and Shewanella putrefaciens $(15,28)$. Spoilage can also be caused by Clostridium spp., which is able to grow at refrigeration temperatures $(6,15)$. The "blowing" of vacuum packages due to microorganisms has been reported $(5,8)$.

Several microorganisms have been found in vacuumpackaged chilled meat, including lactic acid bacteria (LAB) such as Lactobacillus spp., Leuconostoc spp., Carnobacterium spp. and B. thermosphacta. Bacteria from the genera Enterobacter, Serratia, Hafnia and Rahnella (5) and Clostridium, such as C. estertheticum, C. laramiense (62) $C$. frigidicarnis, C. gasigenes and C. algidixylanolyticum, can also be found $(7,8,46)$ and can cause pack distension.

Brochothrix thermosphacta is an important microorganism that causes spoilage of refrigerated meat. It prefers glucose as a substrate (30). In anaerobic conditions, glucose is metabolized by this organism mainly into lactic acid. In the presence of oxygen, the main products are acetoin and diacetyl, which are present in some cheeses and cause sweat odors $(36,52)$. Thus, the aerobic metabolism of this bacterium is more offensive than the anaerobic metabolism, which results mainly in lactic acid and ethanol (52). There are no reports attributing "blowing" of vacuum packages to Brochothrix thermosphacta.

Soon after packaging, the population of lactic acid bacteria is generally below the limit of detection (10 CFU / g), but it increases during storage (40). Lactic acid bacteria ferment glucose and other substrates that are present in meat. When these substrates are depleted, growth stops, typically when the population reaches $8 \mathrm{log} / \mathrm{cm}^{2}$. The metabolic residues of most lactic acid bacteria are not eliminated, however, and can be identified as slightly acidic or milky tastes (36). In general, the deterioration caused by species such as Lactobacillus curvatus and $L$. sakei is not regarded as particularly undesirable because 
the odor of the volatile fatty acids that are produced by these microorganisms disappears after opening the package (56). Signorini et al. 2006 (61) even recommended the application of some species of lactic bacteria and lactic acid in meat as a means of controlling bacterial populations and increasing shelf life. When lactic bacteria produce $\mathrm{H}_{2} \mathrm{~S}$ from cysteine, however, they produce an unpleasant odor and color. $\mathrm{H}_{2} \mathrm{~S}$ oxidizes myoglobin to metmyoglobin, giving meat a green color. Heterofermentative species produce lactic acid and $\mathrm{CO}_{2}$, which leads to the accumulation of gas and liquid in the package (55). An example of lactic acid bacteria that causes the accumulation of $\mathrm{CO}_{2}$ from 1 to $5^{\circ} \mathrm{C}$ in vacuum-packaged meat is Lactobacillus carnosum (2). Some lactic acid bacteria are more harmful to the quality of meat than others. During prolonged storage in a modified atmosphere, some heterofermentative strains can produce fermentation products such as butyric acid (rancid/ butter-type odor and flavor) and ethanol, which reduce the shelf-life of the product (36).

In Brazil, Bromberg et al. 2003 (10) investigated the microbiological cause for the blowing of meat packages. Their results implicated temperature abuses during storage and the presence of lactic acid bacteria; Clostridium spp. were not detected by conventional techniques.

In 1978, Gill \& Newton (29) reported that, under vacuum, lactic acid bacteria could only reach populations as high as $10^{7}$ CFU/cm2. According to Dainty \& Mackey, 1992 (15), the growth of other bacteria would be limited or very slow in this product. It is known, however, that some other genera, such as Clostridium and Enterobacteriaceae (5), can multiply in vacuum-packaged meat causing deterioration and pack distension at refrigeration temperatures. These microorganisms have been the subject of many studies. Species of Clostridium that are able to grow at refrigeration temperatures have been identified as causative agents of blowing vacuum packages. Recently, new genera, such as Enterobacteriaceae, have also been shown to cause the same problem $(5,9)$.

The deterioration caused by psychrotrophic and psychrophilic Clostridium is associated with proteolysis, loss of texture, accumulation of liquid in packages and an unpleasant smell, mainly hydrogen sulfide gas (55). In anaerobic conditions, proteins are degraded into sulfur compounds, which have strong and disgusting odor. End products of non-protein nitrogen compounds generally include ammonia (34).

Psychrophilic and psychrotrophic Clostridium species have been isolated from cases of premature deterioration and blown pack, including $C$. estertheticum subsp. estertheticum (62), C. estertheticum subsp. laramiense, C. algidicarnis, C. frigidicarnis, C. gasigenes and C. algidixylanolyticum (46, 8, 7). With the exception of $C$. algidicarnis, which spoils but does not produce gas, the other species cited cause the blowing of vacuum packages in approximately four weeks. Gas production in vacuum-packaged meat or "blown pack" type deterioration was initially detected in meats that have suffered temperature abuse in processing and storage (33). It is known, however, that distension problems can occur without temperature abuse (16, 42), and this is a challenge for the production chain, processing and marketing of meats.

The deterioration of vacuum-packaged meat caused by Enterobacteriaceae bacteria is often characterized by unpleasant odors and / or greening of the meat, instead of gas production (5). The proliferation of this bacterium in vacuumpacked meat is generally limited to products with a $\mathrm{pH}$ greater than 5.8 (28) and is more likely to occur with temperature abuses (5) above $6^{\circ} \mathrm{C}$ (36). Enterobacteriaceae species that grow in vacuum-packed meat (Serratia liquefaciens, Hafnia spp) are able to grow at temperatures between 0 and $10^{\circ} \mathrm{C}(43)$. At temperatures above $6^{\circ} \mathrm{C}$, Enterobacteriaceae decarboxylate amino acids, producing organic amines, which have putrid odors and tastes. S. putrefaciens, which preferentially uses cysteine to produce hydrogen sulfide and organic sulfides, can grow in such conditions and contribute to deterioration. Sulfides have an unpleasant odor and can react with myoglobin, resulting in the greening of the meat. Aeromonas spp., which are facultative anaerobic bacteria, can produce a putrid odor and cause the deterioration of high $\mathrm{pH}$ vacuumpackaged pork maintained at $-1.5^{\circ} \mathrm{C}(37)$.

The presence of Enterobacteriaceae in vacuum-packed 
chilled meat is of particular importance, both for its high deteriorating potential and for food safety concerns because some species are pathogens. Recent research in New Zealand (5) on blown packs of chilled fresh meat stored at $4{ }^{\circ} \mathrm{C}$ detected a moderate to high number of Enterobacteria from the following genera: Enterobacter, Serratia, Hafnia and Rahnella. Clostridium, which is generally identified as the cause of blown pack deterioration, was not identified. These researchers demonstrated the potential of Hafnia, Enterobacter, Serratia, Rahnella and Ewingella to cause blown pack, when these species were artificially inoculated $\left(10^{5} \mathrm{CFU} / \mathrm{g}\right)$ in vacuumpacked chilled lamb and stored for 21 days at $4^{\circ} \mathrm{C}$. Facultative anaerobic bacteria such as Enterobacter, Serratia, Proteus and Hafnia metabolize amino acids to produce amines, ammonia, dimethylsulfide and mercaptans and cause putrefaction of the meat. Due to the production of amines and ammonia, the $\mathrm{pH}$ of the meat reaches becomes alkaline, causing a pink to reddish coloration (56).

Recently, other microorganisms have been implicated as causing the deterioration of vacuum-packaged meats but have not been shown to cause blown pack: Serratia spp., Buttiauxella spp., Acinetobacter baumannii, Pseudomonas spp. and Carnobacterium maltaromaticum (21). According to Laursen et al. 2005 (45), other species often found in the microbiota of vacuum-packed meat are Carnobacterium divergens and Carnobacterium maltaromaticum.

\section{Headspace composition of distended packages}

Psychrophilic and psychrotrophic species grow and produce gas at temperatures from 1.5 to $2^{\circ} \mathrm{C}(9,41)$. According to Broda et al. 2000 (8), they can cause distension of vacuum packages in 14 days at temperatures of up to $2^{\circ} \mathrm{C}$. The main gases and volatile compounds produced by bacteria that cause distension of packages are carbon dioxide, hydrogen, butanol, acetic acid, butyric acid and esters (9). Analyses of gas composition and volatile compounds in vacuum-packed meats and other types of modified atmospheres have been done. It was found that within 14 days, the $\mathrm{O}_{2}$ concentration decreases dramatically to $0 \%$ at $5^{\circ} \mathrm{C}$, while the $\mathrm{CO}_{2}$ concentration increases $25 \%$ in these conditions (21). In recent work, this same group identified high levels of aldehyde, lactones and sulfurous components synthesized by Carnobacterium maltaromaticum, as well as alcohol and ketones in samples of meat contaminated with Pseudomonas fragi and alcohol and esters synthesized by Serratia proteamaculans. Thus, several aerobic and anaerobic species can contribute to the deterioration of meats.

Studies on the composition of gases and volatile compounds in vacuum-packaged chilled meat are scarce. The group of Bromberg et al. 2003 (10) detected the presence of $\mathrm{CO}_{2}$ and $\mathrm{H}_{2}$ in rump steak samples with blown pack problems. This gas composition suggests the psychrotrophic Clostridium as probable causative agents; however, this genus was not isolated from the samples studied.

\section{Molecular techniques used to identify the microbiota of vacuum-packaged chilled beef cuts}

Conventional microbiological methods are used to detect bacteria and other organisms in food to assess food safety standards. However, these techniques may not be ideal because the methods are often lengthy; this issue has particular economic importance for foods with a short shelf-life (50). Furthermore, through conventional techniques, it is difficult to clearly identify the majority of isolates involved in the deterioration of vacuum-packaged meat products because the phenotypic characteristics are often shared among species (38). The selective enrichment of cultures may not be able to properly simulate the conditions that the microorganisms require to proliferate (39). The selective media and cultivation conditions that are used in the laboratory can recover some species over others that cannot be grown in standard media.

Thus, cultivation-based methods have limitations in assessing the microbial diversity in food. Inevitably, they require some prior knowledge about the type of bacteria that may be present in the population being tested.

Therefore, in recent decades, there has been a significant increase in the development of molecular techniques for the detection, identification and characterization of pathogenic 
bacteria that deteriorate foods. Advances in molecular biology have enabled the development and use of several molecular methods, based mainly on Polymerase Chain Reaction (PCR). The development of PCR has allowed for the rapid identification of microorganisms (18), and in the last ten years, it has became the genetic technique that is most used in microbiological diagnosis (49). Other molecular techniques, such as T-RFLP (Terminal restriction fragment length polymorphism), AFLP (Adaptor fragment length polymorphism), PCR-ARDRA (PCR-amplification ribosomal DNA restriction analysis), RAPD (Random amplified polymorphic DNA), RT-PCR (Real Time PCR), and DGGE (Denaturing gradient gel electrophoresis), are additional alternatives for identifying and quantifying the microbial diversity found in food (31). These techniques were initially used to analyze environmental samples, such as soil and water, but in recent years, they have been applied to food, for example, in vacuum packed chilled meat (35).

The identification of strict anaerobic Clostridium species is hard by conventional cultivation methods but can be done with PCR instead (3). PCR may be not efficient at identifying closely related species, though, because in some cases it can be difficult to design specific primers with the desirable characteristics. PCR detection of Clostridium associated with blown pack has been done in New Zealand (3) using commercial packs of vacuum-packed lamb samples, and in Brazil, PCR was used to identify Clostridium in vacuum packed chilled meat $(11,58)$.

One molecular tool that not only identifies but quantifies microorganisms is Real Time PCR (RT-PCR), which can identify both pathogenic and non-pathogenic microorganisms. In foods, RT-PCR has been used to analyze Lactobacillus sakei and Leuconoctoc mesenteroides in meat products $(19,50)$.

Sequencing is another tool that is important for microorganism identification. The complete genome sequences of a large number of microorganisms, as well as the sequences of the 16S rDNA gene, are available in public databases (GenBank). This information enables the comparison of nucleotide sequences that are obtained from samples in laboratory. With an analysis of sequences of the 16S rDNA gene from different foods and environmental samples, it has been demonstrated that cultivation-dependent methods have underestimated the true microbial diversity in these samples (1). Methods for the sequencing of genes that encode the $16 \mathrm{~S}$ rRNA have been considered important tools in the study of microbial communities in meat samples, as they produce reliable results.

Recently, research on microbial communities using molecular techniques has been applied in meat deterioration studies: RAPD was used to assess the biodiversity of yeasts, mold and bacteria in sausage (12).

Another technique for the analysis of microbiota in food, DGGE, was used in the microbial assessment of vacuumpacked meats and meat products $(26,27)$. The DGGE technique alone cannot be used to directly determine and identify species or taxonomic groups in a sample, and, therefore, it is necessary to excise the gel amplicon and sequence it (44). The DGGE technique is generally used to evaluate the structure and dynamics of microbial communities in food samples in response to environmental changes without the need for cultivation (22). It is also used to analyze samples subjected to different treatments, according to research of Brightwell et al. 2009 (4), which demonstrated the importance of the combination of cultivation-independent techniques (16S rDNA gene cloning and DGGE) and conventional cultivation techniques in the study of the microbial populations of vacuum-packed meats treated with peracetic acid. In their work, they obtained data that could not have been obtained with the use of conventional and molecular methods alone.

The genetic diversity of a community in a particular environment can be assessed with "Fingerprinting" techniques. One example, AFLP was used to identify and track microorganisms such as Listeria monocytogenes in raw shellfish, chilled food and salmon $(14,32)$. In the case of vacuum-packed meat with blown pack problems, PCR and RFLP have been used to identify $C$. algidicarnis and $C$. putrefaciens using primers for the $\mathrm{V} 1$ and $\mathrm{V} 6$ regions of the 16S RNA gene (3) and to track and identify contamination with 
Enterobacteriaceae, C. estertheticum and C. gasigenes (5, 6, 7). Nonetheless, the use of molecular tools to assess a bacterial community in this type of sample has not been fully explored.

In many cases, it is important to characterize meat microorganisms to know the diversity and trace sources of contamination. Pulsed Field Gel Electrophoresis (PFGE) is another molecular technique for microorganism characterization. PFGE compares genomic DNA profiles and was used recently to estimate the genetic diversity of Clostridium difficile isolated from meat (57). PFGE was also employed to study the diversity of Leuconostoc gasicomitatum isolated from meat products (63). L. gasicomitatum is a psychrotrophic, lactic acid bacterium, that causes meat spoilage by producing gas in modified atmosphere packing. For strict anaerobic species like some Clostridium, PFGE characterization would be more difficult, since the microorganism needs to be isolated to be analyzed by this method.

In conclusion, molecular methods have overcome the limitations associated with selective cultivation and isolation of microorganisms. It is important to consider, however, that molecular methods cannot distinguish DNA isolated from viable versus non-viable bacteria.

\section{Final remarks}

Vacuum packages for fresh meat increase the shelf life and thus improve the distribution efficiency and marketing of the product. Deterioration problems are minimized when the $\mathrm{pH}$ of the meat to be packaged is controlled and ideal storage temperatures are accurately maintained. Even at suitable refrigeration temperatures, however, meat may be subject to deterioration by microorganisms that are able to grow under these conditions in the absence of oxygen. Psychrotrophic and psychrophilic Clostridium species have been shown to cause blown pack type of deterioration; however, other species that produce $\mathrm{CO}_{2}$ such as Enterobacter, Serratia, Hafnia and Rahnella may also contribute. There has been little research on these organisms, especially those that cause the blown pack problem. Molecular techniques are able to detect non- culturable microorganisms, namely strictly anaerobic microorganisms. They can be used to identify species in microbial communities of deteriorated samples, to examine likely interactions between microorganisms and thus to find sources of contamination and develop control strategies. Different molecular techniques for analyzing the diversity of microorganisms have been developed, improved and increasingly applied to foods, which help to control the quality of products. In some cases, the use of molecular techniques together with culture-dependent techniques may be necessary.

\section{ACKNOWLEDGMENTS}

We thanks CNPq and FAPESP for financial support.

\section{REFERENCES}

1. Amann, R.I.; Ludwig, W.; Schleifer, K.H. (1995).Phylogenetic identification and in situ detection of individual microbial cells without cultivation. Microbiol Rev. 59(1): 143-169.

2. Balow, A. (1992). The Prokaryotes: a hand book on the biology of bacteria; Springer-Verlog: New York.

3. Boerema, J.A.; Broda, D.M.; Bell, R.G. (2002). PCR detection of psychrotolerant clostridia associated with deep tissue spoilage of vacuum-packed chilled meat. Lett. Appl. Microbiol. 35(5): 446-450.

4. Brightwell, G.; Clemens, R.; Adam, K..; Urlich, S.; Boerema, J. (2009) Comparison of culture-dependent and independent techniques for characterisation of the microflora of peroxyacetic acid treated, vacuumpackaged beef. Food Microbiol. 26(3): 283-288.

5. Brightwell, G.; Clemens, R.; Urlich, S.; Boerema, J. (2007). Possible involvement of psychrotolerant Enterobacteriaceae in blown pack spoilage of vacuum-packaged raw meat. Int J Food Microbiol. 119 (3): 334-339.

6. Broda, D.M.; Musgrave, D.R.; Bell, R.G. (2003). Molecular differentiation of clostridia associated with "blown pack" spoilage of vacuum-packed meats using internal transcribed spacer polymorphism analysis. Int. J. Food Microbiol. 84(1): 71-77.

7. Broda, D.M.; Bell, R.G.; Boerema, J.A.; Musgrave, D.R. (2002) The abattoir source of culturable psychrophilic Clostridium spp causing "blown pack" spoilage of vacuum-packed chilled venison. J Appl Microbiol. 93(5): 817-824.

8. Broda, D.M.; Saul, D.J.; Lawson, P.A.; Bell, R.G.; Musgrave, D.R. (2000). Clostridium gasigenes sp. nov. a psychrophile causing spoilage of vaccum-packed meat. Int J Syst Evol Microbiol. 50(1): 107-118. 
9. Broda, D.M.; De Lacy, K.M.; Bell, R.G.; Bragiins, T.J.; Cook, R.L. (1996 a). Psychrotrophic Clostridium spp. associated with "blown pack" spoilage of chilled vaccum-packed red meats and dog rolls in gasimpermeable plastic casings. Int J Food Microbiol. 29 (1-2): 335-352.

10. Bromberg, R.; Oliveira, J.; Junqueira, V.C.A. (2003). Microorganisms associated with "blown pack"spoilage of chilled vacuum-packed beef. $49^{\text {th }}$ International Congress of Meat Science and Technology. $2^{\text {nd }}$ Brazilian Congress of Meat Science and Technology, Campinas-SPBrazil.

11. Bueno, C. P.;, Mesquita, A. J.; Melo, C. S.; Mesquita, A. Q.; Rezende. C. S. M.; Prado, C. S. (2009). Diagnóstico molecular DE Clostridium esterheticum estertheticum e Clostridium estertheticum like em carnes refrigeradas embaladas a vácuo. V Congresso Brasileiro de Ciência e Tecnologia de Carnes, São Paulo-SP- Brazil

12. Cocolin, L.; Rantsiou, K.; Iacumin, L.; Urso, R.; Cantoni, C.; Comi, G. (2004). Study of the ecology of fresh sausages and characterization of populations of lactic acid bacteria by molecular methods. Appl Environ Microbiol. 70(4):1883-1894. Commonwealth Scientific and Research Organization (CSIRO) Meat technology update. November, 2006. Food Science Australia. A joint venture of Australian Commonwealth Scientific and Research Organization \& the Victorian Government. Available at: http://www.meatupdate.csiro.au/data/MEAT TECHNOLOGYUPDATE00-5.pdf.

13. Commonwealth Scientific and Research Organization (CSIRO) Meat technology update. November, 2006. Food Science Australia. A joint venture of Australian Commonwealth Scientific and Research Organization \& the Victorian Government. Available at: http://www.meatupdate.csiro.au/data/MEATTECHNOLOGYUPDATE 00-5.pdf.

14. Corcoran, D.; Clancy D.; O’Mahony, M.; Grant, K.; Hyland, E.; Shanaghy, N.; Whyte, P.; McLauchlin, J.; Moloney, A.; Fanning, S. (2006). Comparison of Listeria monocytogenes strain types in Irish smoked salmon and other foods J. Hyg. Environ. Health. 209(6): 527534.

15. Dainty, R.H.; Mackey, B.M. (1992). The relationship between the phenotypic properties of bacteria from chilled-stored meat and spoilage processes. J Appl Microbiol. 73 (suppl): 103S-114S.

16. Dainty, R.H.; Edwards, R.A.; Hibbarb, C.M. (1989). Spoilage of vacuum-packed beef by a Clostridium sp. J Sci Food Agric, 49 (4):.473486.

17. Egan, A F. (1983). Lactic acid bacteria of meat and meat products. Antonie Van Leeuwenhoek. 49(3): 327-336.

18. Eley, A. (1993). New Molecular Methods for the Detection of Bacteria in Food. Nutr Food Sci. 93 (2): 9 - 13.

19. Elizaquível, P.; Chenoll, E.; Aznar, R. (2008). A TaqMan-based real-time PCR assay for the specific detection and quantification of Leuconostoc mesenteroides in meat products. FEMS Microbiol Lett. 278(1):62-71.

20. Ellis, D.I. Goodacre, R. (2001). Rapid and quantitative detection of the microbial spoilage of muscle foods: current status and future trends.
Trends Food Sci. Technol. 12(11):414-424.

21. Ercolini, D.; Russo, F.; Nasi, A.; Ferranti, P.; Villani, F. (2009). Mesophilic and psychrotrophic bactéria from meat and their spoilage potential in vitro and in beef. Appl Environ Microbiol. 75(7):1990:2001.

22. Ercolini, D.; Mauriello, G.; Blaiotta, G.; Moschetti, G.; Coppola, S. (2004 b). PCR-DGGE fingerprints of microbial succession during a manufacture of traditional water buffalo mozzarella cheese. J Appl Microbiol. 96(2004):263-270.

23. Eustace, I J. (1981). Some factors affecting oxygen transmission rates of plastic films for vacuum packaging of meat. J Food Technol. 16 (1):7380.

24. Felipe L.M. (2008). Associação De Bactérias Da Família Enterobacteriaceae e Clostridium estertheticum com a Deterioração "Blown Pack" em Cortes Cárneos Embalados a Vácuo. Brasil, 181p. (PhD Dissertation. Faculdade de Ciências Agrárias e Veterinárias UNESP- Jaboticabal).

25. Fleet, G H. (1999) Microorganisms in food ecosystems. Int $J$ food Microbiol. 50 (1-2):101-117.

26. Fontana C, Sandro Cocconcelli P, Vignolo G. (2005 a). Monitoring the bacterial population dynamics during fermentation of artisanal Argentinean sausages. Int J Food Microbiol. 103(2):131-142.

27. Fontana C, Vignolo G, Cocconcelli PS. (2005 b). PCR-DGGE analysis for the identification of microbial populations from Argentinean dry fermented sausages. J Microbiol Methods. 63(3):254-63.

28. Gill, C.O. (2004). Spoilage factors affecting. In: Jensen, W.J., Devine, C.E., Dikeman, M. (Eds.), Encyclopaedia of Meat Science. Elsevier Ltd, Oxford, UK, pp. 1324-1330.

29. Gill, C.O.; Newton, K.G. (1978). The ecology of bacterial spoilage of fresh meat at chill temperatures. Meat Sci. 2(3): 207-217.

30. Gill, C.O.; Newton, K.G. (1977). The development of aerobic spoilage flora on meat stored at chill temperatures. J Appl. Microbiol. 43(2):189195.

31. Giraffa, G.; Lazzi, C.; Gatti, M.; Rossetti, L.; Mora, D.; Neviani, E. (2003). Molecular typing of Lactobacillus delbrueckii of dairy origin by PCR-RFLP of protein-coding genes. In.t J. Food Microbiol. 82(2): 163172.

32. Guerra m, M.; Bernardo, F.; McLauchlin J. (2002). Amplified Fragment Length Polymorphism (AFLP) Analysis of Listeria mono, cytogenes. Appl. Microbiol. 25(3): 456-461.

33. Hanna, M.O.; Stewart, J.C.; Carpenter, Z.I.; Zink, D.L.; Vanderzant, C. (1979). Isolation and characteristics of Yersinia enterocolitica-like bacteria from meats. Contrib Microbiol Immunol. 5: 234-242.

34. Hedrick, H.B.; Aberle, E.D.; Forrest, J.C.; Judge, M.D.; Merkel, R.A. (1993). Principles of meat science. Dubuque: Kendall/Hunt Publishing Company.

35. Hernandez-Macedo, M. L.; Zari, A, C.; Siu Mui Tsai.; Sarantópoulus, C.; Padula, M.; Contreras-Castillo, C. J. (2009). Identificação e análise da comunidade microbiana em carnes refrigeradas embaladas a vácuo com problema do tipo "blown pack". V Congresso Brasileiro de Ciência e 
Tecnologia de Carnes, São Paulo- SP- Brasil

36. Holley, R.A.; Gill, C O. (2005). Usos da embalagem em atmosfera modificada para carnes $\mathrm{e}$ produtos cárneos. Available at: www.ital.sp.gov.br/ctc/eventos/terceiro_congresso/5.doc). Accessed 26 July 2009.

37. Holley, R.A.; Peirson M.D.; Lam, J.; Tan, K.B. (2004). Microbial profiles of commercial, vacuum-packaged, fresch pork of normal or short storage life. Int J Food Microbiol. 97(1):53-62.

38. Holley, R. A. (1997). Impact of slicing hygiene upon shelf life and distribution of spoilage bacteria in vacuum packaged cured meats. Food Microbiol. 14(3): 201-211.

39. Hu, P; Zhou, G; Xu, X; Li, C; Han, Y. (2009). Characterization of the predominant spoilage bacteria in sliced vacuum-packed cooked ham based on 16S rDNA-DGGE. Food Control. 20(2): 99-104.

40. Jones, R. J. (2004). Observations on the succession dynamics of lactic acid bacteria populations in chill-stored vacuum-packaged beef. Int $J$ Food Microbiol. 90(3):273-282.

41. Kalchayanand, N.; Ray, B.; Field, R.A. (1993). Characteristics of Psychrotrophic Clostridium laramie causing spoilage of vacuumpackaged refrigerated fresh and roasted beef. J. Food Prot. 56(1): 13-17.

42. Kalchayanand, N.; Ray, B.; Field, R.A.; Johnson M.C. (1989). Spoilage of vacuum-packaged refrigerated beef by Clostridium. J. Food Prot. 52 (6): 424-426.

43. Labadie, J. (1999). Consequences of packaging on bacterial growth. Meat is an ecological niche. Meat Sci. 52(3):299-305.

44. Lambais, M.R.; Cury, J.C.; Maluche-Baretta, C.; Bull, R.C. (2005). Diversidade microbiana nos solos: definindo novos paradigmas. In: Vidal-Torrado, P.; Alleoni, L. R.F.; Cooper, M.; Silva, A.P.; Cardoso, E.J. (Ed.). Tópicos em ciência do solo. Viçosa: Sociedade Brasileira de Ciência do Solo. V. 4, p.43-84.

45. Laursen, B.G.; Bay, L.; Cleenwerck, I.; Vancanneyt, M.; Swings, J.; Dalgaard, P.; Leisner, J.J. (2005). Carnobacterium divergens and Carnobacterium maltaromaticum as spoilers or protective cultures in meat and seafood: phenotypic and genotypic characterization. Syst. Appl. Microbiol. 28(2):151-164.

46. Lawson, P.; Dainty, R.H.; Kristiansen, N.; Berg, J.; Collins, M.D. (1994). Characterisation of a psychrotrophic Clostridium causing spoilage in vacuum-packed cooked pork: description of Clostridium algidicarnis sp. nov. Lett. App. Microbiol. 19(3): 153-157.

47. Lebert, I.; Begot, C.; Lebert, A. Growth of Pseudomonas fluorescens and Pseudomonas fragi in a meat medium as affected by $\mathrm{pH}(5.8-7.0)$, water activity (0.97-1.00) and temperature $\left(7-25^{\circ} \mathrm{C}\right)$. (1998). Int J Food Microbiol. 39 (1-2):53-60.

48. Luchiari Filho, A. (2006) Produção de carne bovina no Brasil: qualidade, quantidade ou ambas? II SIMBOI - Simpósio sobre Desafios e Novas Tecnologias na Bovinocultura de Corte, Brasília-DF. Availavel: http://www.upis.br/simboi/anais/Produ\%C3\%A7\%C3\%A3o\%20de\%20C arne $\% 20$ Bovina\%20no\%20Brasil\%20\%20Albino\%20Luchiari\%20Filho. pdf.

49. Malorny, B.; Paccassoni, E.; Fach, P.; Bunge, C.; Martin, A.; Helmuth, R. (2004). Diagnostic Real-Time PCR for Detection of Salmonella in Food. Appl Environ Microbiol. 70(12): 7046-7052.

50. Martin, B.; Jofrè, A.; Garriga, M.; Pla M.; Aymerich, T. (2006). Rapid quantitative detection of Lactobacillus sakei in meat and fermented sausages by Real-Time PCR, Appl Environ Microbiol. 72 (9): 60406048 .

51. Nychas, G.E.; Skandamis, P.N.; Tassou, C.C. Koutsoumanis, K.P. (2008). Meat spoilage during distribution. Meat Sci. 78(1-2):77-89.

52. Pin, C.; De Fernando, G.D.G.; Ordönez, J.A. (2002). Effect of Modified Atmosphere composition on the metabolism of glucose by Brochothrix thermosphacta. Appl Environ Microbiol. 68(9): 4441-4447.

53. Rauecker, U.N.; Del'acqua, T.V.; Mesquita, A.Q.; Nunes, I.A; Mesquita, A.J. (2006). Deteç̧ão de Clostridium estertheticum e Clostridium gasigenes incriminados na deterioração de carnes bovinas refrigeradas embaladas a vácuo através da técnica de PCR. III Congresso De Pesquisa, Ensino e Extensão da UFG-CONPEEX, Goiânia- GO. Anais eletrônicos do III Seminário de Pós-Graduação da UFG [CD-ROM].

54. Rauecker, U.N.; Nunes, I.A.; Miguel, M.P.; Ramos, R.R.; Puça, M.L.L.; França, L.; Mori, A.; Bueno, C.P.; Mesquita, A.J. (2005). Deteç̧ão de Clostridium estertheticum e Clostridium gasigenes incriminados na deterioração de carnes bovinas refrigeradas embaladas a vácuo, através da técnica de PCR. II Congresso de Pesquisa, Ensino e Extensão da UFG - CONPEEX, Goiânia- GO. Anais eletrônicos do II Seminário de PósGraduação da UFG [CD-ROM].

55. Ray, B.; Bhunia, A. (2008). Fundamental food microbiology. CRC Press, Boca Raton- FL.

56. Ray, B. (2000). Fundamental food microbiology. CRC Press, Boca Raton- FL.

57. Rodriguez-Palacios, A.; Reid-Smith, R.J.; Staempfli, H.R.; Daignault, D.; Janecko, N.; Avery, B.P.; Martin, H.; Thomspon, A.D.; McDonald, L.C.; Limbago, B.; Weese, J.S. (2009). Possible Seasonality of Clostridium difficile in retail meat, Canada. Emerging Infectious Diseases, 15(5): 802-805.

58. Rosa, V.P. (2009). Clostridium estertheticum e Clostridium gasigenes: detecção, isolamento, rastreamento e controle no processamento de carne bovina resfriada embalada a vácuo. Campinas-SP, Brasil, 181p. (PhD Dissertation. Faculdade de Engenharia de Alimentos. UNICAMP).

59. Sarantópoulos, C.I.G.L.; De Oliveira, L.M.; Canavesi, E. (2001). Carnes, aves, pescados e derivados. Requisitos de conservação de alimentos em embalagens flexíveis. Campinas, SP: CETEA, 151-174.

60. Sarantópoulos, C.; Soler, R. (1991) Embalagens com atmosfera modificada/controlada. Rev Nac Carne. 209:32-42.

61. Signorini, M.L.; Ponce-Alquicira, E.; Guerreiro-Legarreta, I. (2006). Effect of lactic acid and acid bacteria on growth of spoilage microorganisms in vacuum-package beef. J Muscle Foods. 17(3): 277290. 
62. Spring, S.; Merkhoffer, B.; Weiss, N.; Kroppenstedt, R. M.; Hippe, H.; Stackebrandt, E. (2003). Characterization of novel psychrophilic clostridia from an Antartic microbial mat: description of Clostridium frigoris sp. nov., Clostridium lacusfryxellense sp. nov., Clostridium bowmanii sp. nov. and Clostridium psychrophilum sp. nov. and reclassification of Clostridium laramiense as Clostridium estertheticum subsp. laramiense subsp. nov. Int. J. Syst. Evol. Microbiol. 53(4): 10191029.

63. Vihavainen, E.J.; Bojörkrothv, J. (2009). Diversity of Leuconostoc gasicomitatum associated with meat spoilage. Int. J. Food Microbio. 136 (1): 32-36. 